\title{
COMPARATIVE EVALUATION OF CLASSICAL SUBARACHNOID BLOCK, UNILATERAL SUBARACHNOID BLOCK AND LOW-DOSE SUBARACHNOID BLOCK IN HIGH-RISK PATIENTS UNDERGOING LOWER LIMB SURGERIES
}

\author{
Setty Arumugam Namasivayam1, Mariappan Gomathi2, Raju Sudhakar ${ }^{3}$
}

${ }_{1}^{1}$ Associate Professor, Department of Anaesthesiology, Government Vellore Medical College Hospital, Adukkamparai, Vellore. ${ }^{2}$ Associate Professor, Department of Anaesthesiology, Government Vellore Medical College Hospital, Adukkamparai, Vellore. ${ }^{3}$ Associate Professor, Department of Anaesthesiology, Government Vellore Medical College Hospital, Adukkamparai, Vellore.

\section{ABSTRACT}

\section{BACKGROUND}

Subarachnoid block is a popular anaesthetic technique because of its rapid onset, safety and simplicity. A special technique of subarachnoid block named spinal hemi-block was described for one-limb surgeries, which was also known as spinal hemianalgesia or unilateral spinal anaesthesia. Addition of fentanyl to bupivacaine is an established technique to reduce the dose of anaesthetic and to maintain haemodynamic(1) stability.

\section{FACTORS AFFECTING UNILATERAL SPINAL}

Five main factors should be considered when trying to restrict spinal block (2) to the operative side. 1 . The density of local anaesthetic solution compared with CSF.(3) 2. Speed of intrathecal injection.(4) 3. Patient position.(5) 4. Dose, Concentration, volume of the local anaesthetic solution. 5. Design of spinal needles.

\section{AIM}

To compare the efficacy of classical subarachnoid block using $0.5 \%$ bupivacaine, unilateral subarachnoid block using $0.5 \%$ bupivacaine and low-dose subarachnoid block using $0.5 \%$ bupivacaine $1.5 \mathrm{~mL}$ with $0.5 \mathrm{~mL}$ of fentanyl(2) (25 micrograms) in highrisk patients undergoing unilateral lower limb surgeries( $\left.{ }^{6}\right)$ based on the following parameters. 1 . Haemodynamic stability in the intraoperative period. 2. Onset and Quality of subarachnoid block.

\section{MATERIALS AND METHODS}

A total of 60 high-risk patients undergoing surgery on one lower limb were divided into three groups. Control Group-Received $2 \mathrm{~mL}$ of $0.5 \%$ Bupivacaine intrathecally and turned to supine position immediately. Study Group I: Received $1.5 \mathrm{~mL}$ of $0.5 \%$ Bupivacaine with $25 \mu \mathrm{g}(0.5 \mathrm{~mL})$ Fentanyl intrathecally and kept in lateral decubitus position for 10 minutes and then turned supine. Study Group II: Received $2 \mathrm{~mL}$ of $0.5 \%$ Bupivacaine intrathecally and kept in lateral decubitus position for 10 minutes and then turned supine. Heart rate, Systolic and Diastolic blood pressure were recorded before and after the spinal every five minutes for 60 minutes and in the recovery room and thereafter every 30 minutes till the time oral analgesic was given. Sensory blockade was assessed in the dependent as well as non-dependent limb separately. Using Modified Bromage scale, both the dependent as well as non-dependent limbs were assessed separately for the motor blockade at $0,5,10,15$ and every 5 minutes after surgical position. Side effects such as nausea, vomiting, and pruritus were recorded in the intraoperative and postoperative period.

\section{RESULTS}

The occurrence of hypotension requiring treatment was more in the control group (30\%) versus Study Group I(15\%) and Study Group II(15\%) which is statistically significant $(\mathrm{p}<0.02)$. The occurrence of bradycardia requiring treatment was more in the Control group (30\%) versus Study Group I(15\%) and Study Group II(15\%) which is statistically significant (p<0.02). An analysis of motor blockade in the 3 groups showed that Study Group I and Study Group II produced lesser degree of motor blockade when compared to the Control Group. This difference was found to be statistically significant $(\mathrm{p}<0.05)$.

\section{CONCLUSION}

We conclude that in high-risk patients undergoing unilateral lower limb surgeries: 1 . Unilateral low-dose subarachnoid block offers better haemodynamic stability during the intraoperative period. 2. The onset and quality of level of sensory block in unilateral subarachnoid and low-dose unilateral subarachnoid block is same as those produced by classical subarachnoid block. 3 . There is sparing of motor block in the non-dependent limb in unilateral subarachnoid block and unilateral low-dose subarachnoid block.

\section{KEYWORDS}

Classical Subarachnoid Block; Unilateral Spinal, Low-dose spinal, Fentanyl.

HOW TO CITE THIS ARTICLE: Namasivayam SA, Gomathi M, Sudhakar R. Comparative evaluation of classical subarachnoid block, unilateral subarachnoid block and low-dose subarachnoid block in high-risk patients undergoing lower limb surgeries. J.Evolution Med. Dent. Sci. 2016;5(79):5919-5923, DOI: 10.14260/jemds/2016/1336

Financial or Other, Competing Interest: None.

Submission 26-08-2016, Peer Review 19-09-2016,

Acceptance 26-09-2016, Published 03-10-2016.

Corresponding Author:

Dr. Setty Arumugam Namasivayam,

Associate Professor, Department of Anaesthesiology,

Government Vellore Medical College Hospital,

Adukkamparai, Vellore-632011.

E-mail: sanamasivayam@gmail.com

DOI: $10.14260 /$ jemds/2016/1336

\section{INTRODUCTION}

It was in the year 1899, August Bier, used subarachnoid block and he gave first deliberate spinal anaesthesia. Subarachnoid block continued to be most common anaesthetic technique because of its rapid onset, safety and simplicity. Even this relatively safe technique can have complication such as hypotension which a normal patient can tolerate but can be detrimental to patients with haemodynamic instability. The safety improves if the block can be localised to the area of surgery. 
A special technique of subarachnoid block named spinal hemi-block was described for one limb surgeries, which was named as spinal hemianalgesia. This is also known as unilateral spinal anaesthesia. The distance between the left and right spinal roots is only 10-15 millimetre in the lumbar or lower thoracic level. Such a small distance should reasonably prevent from producing strictly unilateral block of the spinal nerve roots. However, various clinical reports suggested that using small doses of either hypo or hyperbaric anaesthetic solution injected at low speeds. (7)(8)(9)(10) through directional needles in patients lying in the lateral decubitus position for 10-15 minutes results in preferential distribution of subarachnoid block towards the operated side, providing intense surgical block on that side. Even though the term unilateral subarachnoid block has been in vogue for a long time most of the research on this is recent. Even though performing subarachnoid block is technically easier, the complications which are usually expected like hypotension and bradycardia can be detrimental to this high-risk group patients.

Addition of fentanyl to bupivacaine is an established technique to reduce the dose of anaesthetic and to maintain haemodynamic stability. However addition of fentanyl can change the baricity of the local anaesthetic and can alter the effect of intended unilateral spinal analgesia.

\section{Factors Affecting Unilateral Spinal Anaesthesia}

Five main factors should be considered when trying to restrict spinal block to the operative side.

1. The density of local anaesthetic solution compared with CSF.

2. Patient position.

3. Speed of intrathecal injection.(11)

4. Dose, Concentration, volume of the local anaesthetic solution.(12)

5. Design of spinal needles.

This study was done to compare the efficacy of classical subarachnoid block, unilateral subarachnoid block, low-dose subarachnoid block in high-risk patients undergoing lower limb surgeries.

\section{AIM}

To compare the efficacy of classical subarachnoid block using, $0.5 \%$ bupivacaine,(11) unilateral subarachnoid block using $0.5 \%$ bupivacaine ${ }^{(12)}$ and low-dose subarachnoid block using $0.5 \%$ bupivacaine $1.5 \mathrm{~mL}$ with $0.5 \mathrm{~mL}$ of fentanyl (25 micrograms) in high-risk patients undergoing unilateral lower limb surgeries based on the following parameters.

1. Haemodynamic stability in the intraoperative period.

2. Onset and Quality of subarachnoid block.

\section{MATERIALS AND METHODS}

The effect of lateral position on maintaining unilaterality of subarachnoid block and the effect of adding fentanyl to hyperbaric bupivacaine in achieving unilateral subarachnoid block undergoing lower limb surgeries on one limb was studied in a total of 60 patients. The study was approved by the institutional research and ethics committee.

\section{Inclusion Criteria}

1. Patients between 18 to 80 years of age.

2. Patients belonging to ASA physical status II and III.

3. Undergoing unilateral lower limb surgery.

\section{Exclusion Criteria}

1. All contraindication for central neuraxial block.

2. Patients who are not cooperative to positioning for subarachnoid block.

3. Patients with anomalies of the spinal column.

\section{Randomisation}

The patients were allocated into three groups by simple randomisation using sealed envelope method. They were divided into three groups.

\section{Control Group}

Received $2 \mathrm{~mL}$ of $0.5 \%$ Bupivacaine intrathecally and turned to supine position immediately.

\section{Study Group I}

Received $1.5 \mathrm{~mL}$ of $0.5 \%$ Bupivacaine with $25 \mu \mathrm{g}(0.5 \mathrm{~mL})$ Fentanyl intrathecally and kept in lateral decubitus position for 10 minutes and then turned supine.

\section{Study Group II}

Received $2 \mathrm{~mL}$ of $0.5 \%$ Bupivacaine intrathecally and kept in lateral decubitus position for 10 minutes and then turned supine.

\section{Preoperative Preparation}

The procedure was explained and the informed consent was obtained. When the patient reached the operating room, monitors were attached which included electrocardiogram, noninvasive blood pressure and pulse oximetry. A wide bore cannula was inserted and the patient was preloaded with 20 $\mathrm{mL} / \mathrm{kg}$ of crystalloid solution. All baseline vital parameters were recorded.

The investigation was blinded to the drug as the study solution was prepared by an anaesthesiologist who was not involved with the administration of subarachnoid block and in the monitoring of the patients. The procedure was done by the investigator on all patients to maintain uniformity of technique. Using 23 gauge Quincke spinal needle with the patient in lateral position (The side to be operated on as the dependent side), the drug was given after assuring free flow of CSF. Patients were kept in the lateral position for 10 minutes after which the patient was positioned for surgery to proceed. The following variables were assessed and recorded in the operative period.

Heart rate, Systolic and Diastolic blood pressure was checked every three minutes and were recorded before the spinal and every five minutes for 60 minutes and in the recovery room and there after every 30 minutes till the time oral analgesic was given. Bradycardia was defined as heart rate less than $60 /$ minute. If bradycardia is symptomatic 0.5 $\mathrm{mg}$ of atropine was given intravenously. Hypotension was defined as drop in systolic blood pressure less than or equal to $30 \%$ below baseline which was treated with rapid infusion of crystalloid in $200 \mathrm{~mL}$ Ringer lactate boluses and/or $6 \mathrm{mg}$ of ephedrine was given intravenously and repeated if necessary.

Sensory blockade was assessed in the dependent as well as non-dependent limb separately. Sensation was assessed using pinprick by a blinded observer. This was recorded every 5 minutes after surgical position for 60 minutes. The sensory levels were checked in the postoperative period in the recovery room. 
Motor blockade was assessed using Modified Bromage scale.

\section{Modified Bromage Scale}

0 - No Motor Block.

1 - Can flex knee, move foot, but cannot raise leg.

2 - Can move foot only.

3 - Cannot move foot or knee.

Both the dependent as well as non-dependent limbs were assessed separately for the motor blockade at $0,5,10,15$ and every 5 minutes for a total period of 60 minutes after surgical position.

Side effects such as nausea, vomiting, and pruritus were recorded in the intraoperative and postoperative period.

\section{STATISTICAL METHOD}

The data analysis was done using SPS SPC+Software. Comparison of the means between the groups was done by Student t-test or chi-square test.

$P$ value $<0.05$ was considered significant.

\section{RESULTS}

\section{Demographic Data}

There were 60 patients in this study. Each group consisted of 20 patients. Patients characteristic for age, sex, height were comparable in all three groups. This is shown in Table I, Table II and Table III.

\begin{tabular}{|c|c|c|c|}
\hline \multirow{2}{*}{$\begin{array}{c}\text { Age } \\
\text { (Years) }\end{array}$} & $\begin{array}{c}\text { Control } \\
\text { Group }\end{array}$ & $\begin{array}{c}\text { Study } \\
\text { Group I }\end{array}$ & $\begin{array}{c}\text { Study } \\
\text { Group II }\end{array}$ \\
\cline { 2 - 4 } & $\mathrm{n}=3$ & $\mathrm{n}=1$ & $\mathrm{n}=1$ \\
\hline $17-26$ & $\mathrm{n}=3$ & $\mathrm{n}=1$ & $\mathrm{n}=1$ \\
\hline $26-36$ & $\mathrm{n}=7$ & $\mathrm{n}=2$ & $\mathrm{n}=4$ \\
\hline $37-46$ & $\mathrm{n}=3$ & $\mathrm{n}=5$ & $\mathrm{n}=4$ \\
\hline $47-56$ & $\mathrm{n}=4$ & $\mathrm{n}=11$ & $\mathrm{n}=10$ \\
\hline $57-66$ & \multicolumn{3}{|c|}{ Table I: The Distribution of Patients according } \\
to age were similar in all Three Groups \\
\hline
\end{tabular}

P-Values control group I and Group $\mathrm{II}=0.879$ (Not Significant), P-Values control group I and Group II $=0.486$ (Not Significant)

\begin{tabular}{|c|c|c|c|c|}
\hline \multirow[b]{2}{*}{ Sex } & \multicolumn{4}{|c|}{ No. of Patients } \\
\hline & $\begin{array}{l}\text { Control } \\
\text { Group }\end{array}$ & $\begin{array}{c}\text { Study } \\
\text { Group I }\end{array}$ & $\begin{array}{l}\text { Study } \\
\text { Group II }\end{array}$ & \multirow{3}{*}{$\begin{array}{c}\text { P value of control } \\
\text { and Study Group I \& } \\
0.675(\mathrm{NS}) \\
\text { P value of control } \\
\text { and Study Group II \& } \\
0.25(\mathrm{NS})^{*}\end{array}$} \\
\hline Female & $\begin{array}{c}n=8 \\
(40 \%)\end{array}$ & $\begin{array}{c}n=10 \\
(50 \%)\end{array}$ & $\begin{array}{c}n=7 \\
(35 \%)\end{array}$ & \\
\hline Male & $\begin{array}{c}n=12 \\
(60 \%)\end{array}$ & $\begin{array}{c}n=10 \\
(50 \%)\end{array}$ & $\begin{array}{l}n=13 \\
(65 \%)\end{array}$ & \\
\hline \multicolumn{5}{|c|}{$\begin{array}{l}\text { Table II: Depicts the Distribution of Males and } \\
\text { Females in all Three Groups were Similar }\end{array}$} \\
\hline
\end{tabular}

*NS-Not Significant

\begin{tabular}{|c|c|c|c|}
\hline Height & $\begin{array}{c}\text { Control } \\
\text { Group }\end{array}$ & $\begin{array}{c}\text { Study } \\
\text { Group I }\end{array}$ & $\begin{array}{c}\text { Study } \\
\text { Group II }\end{array}$ \\
\hline $151-165$ & $\mathrm{n}=1$ & $\mathrm{n}=1$ & $\mathrm{n}=2$ \\
\hline $156-160$ & $\mathrm{n}=3$ & $\mathrm{n}=8$ & $\mathrm{n}=3$ \\
\hline $161-165$ & $\mathrm{n}=9$ & $\mathrm{n}=8$ & $\mathrm{n}=6$ \\
\hline $166-170$ & $\mathrm{n}=5$ & $\mathrm{n}=1$ & $\mathrm{n}=9$ \\
\hline $171-175$ & $\mathrm{n}=2$ & $\mathrm{n}=2$ & $\mathrm{n}=0$ \\
\hline Total & $\mathbf{n}=\mathbf{2 0}$ & $\mathbf{n}=\mathbf{2 0}$ & $\mathbf{n}=\mathbf{2 0}$ \\
\hline \multicolumn{3}{|c|}{} & $\begin{array}{c}\text { Table III: Distributions of Height in all } \\
\text { Three Groups studied were Similar }\end{array}$ \\
\hline
\end{tabular}

The demographic data reveals that all 3 groups are comparable on height, weight and sex ratios. There is no statistically significant difference between the groups with regard to demographic data.

Haemodynamics (Heart Rate, Blood Pressure).

\section{Heart Rate}

\begin{tabular}{|c|c|c|c|}
\hline Groups & $\begin{array}{l}\text { Control } \\
\text { Group }\end{array}$ & \begin{tabular}{|c|} 
Study \\
Group I
\end{tabular} & $\begin{array}{l}\text { Study } \\
\text { Group II }\end{array}$ \\
\hline Total & $n=20$ & $n=20$ & $n=20$ \\
\hline $\begin{array}{c}\text { Bradycardia Requiring } \\
\text { Treatment }\end{array}$ & $n=6$ & $n=3$ & $n=3$ \\
\hline Percentage & $30 \%$ & $15 \%$ & $15 \%$ \\
\hline \multicolumn{4}{|c|}{$\begin{array}{c}\text { Table IV: Shows the Incidence of Symptomatic } \\
\text { Bradycardia in the Three Groups }\end{array}$} \\
\hline
\end{tabular}

$\mathrm{P}=0.02$ (Statistically significant).

Bradycardia-Heart rate $<60$ beats $/ \mathrm{min}$.

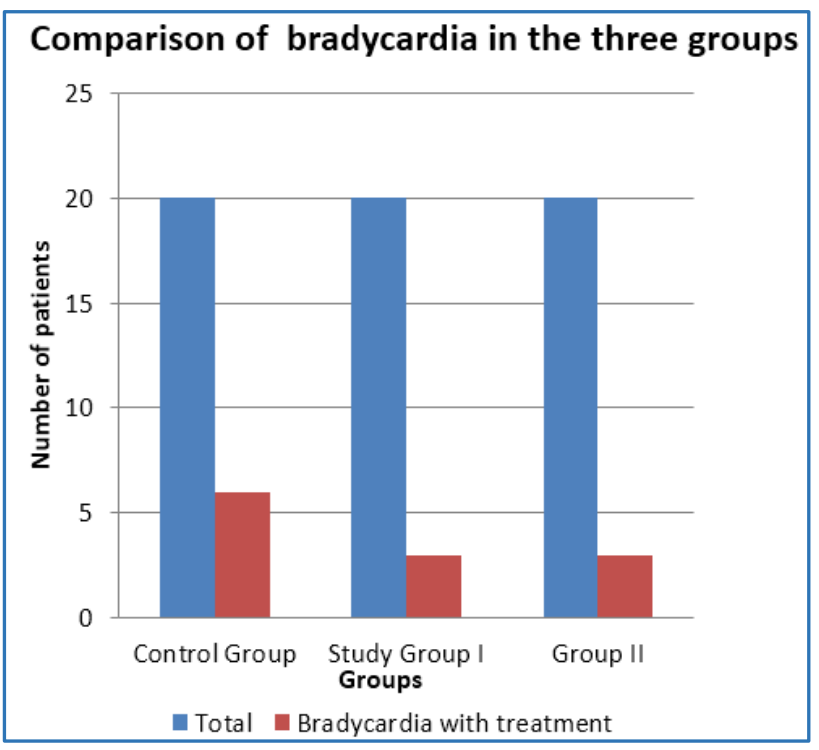

Heart rate comparison revealed that the occurrence of bradycardia requiring treatment was more in control group (30\%) versus the Study Group I (15\%) and Study Group II (15\%). This difference was found to be statistically significant.

\section{Blood Pressure}

\begin{tabular}{|c|c|c|c|}
\hline Groups & $\begin{array}{c}\text { Control } \\
\text { Group }\end{array}$ & $\begin{array}{c}\text { Study } \\
\text { Group I }\end{array}$ & $\begin{array}{c}\text { Study } \\
\text { Group II }\end{array}$ \\
\hline Total & $n=20$ & $n=20$ & $n=20$ \\
\hline $\begin{array}{c}\text { Hypotension } \\
\text { Requiring Treatment }\end{array}$ & $\mathrm{n}=6$ & $\mathrm{n}=3$ & $\mathrm{n}=3$ \\
\hline Percentage & $30 \%$ & $15 \%$ & $15 \%$ \\
\hline \multicolumn{4}{|c|}{$\begin{array}{l}\text { Table V: Shows the Incidence of } \\
\text { Hypotension in the Three Groups }\end{array}$} \\
\hline
\end{tabular}

$\mathrm{P}=0.02$ (Statistically significant).

Hypotension-Systolic drop of blood pressure more than $30 \%$ from the baseline. 


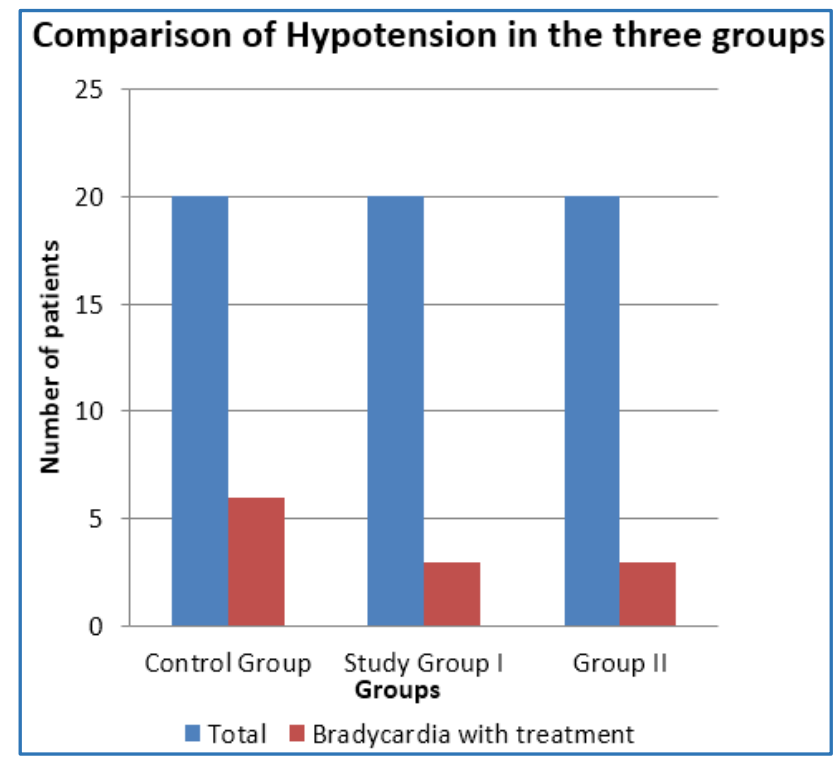

Hypotension comparison revealed that the occurrence of hypotension requiring treatment was more in control group (30\%) versus the Study Group I (15\%) and Study Group II (15\%). This difference was found to be statistically significant.

\section{Motor Blockade}

\begin{tabular}{|c|c|c|c|c|c|c|c|c|c|}
\hline \multirow{5}{*}{$\begin{array}{c}\text { At } \\
15 \\
\text { Minutes }\end{array}$} & \multicolumn{5}{|c|}{ Dependent } & \multicolumn{4}{|c|}{ Non-dependent } \\
\hline & $\begin{array}{c}\text { Bromage } \\
\text { Scale }\end{array}$ & 0 & 1 & 2 & 3 & 0 & 1 & 2 & 3 \\
\hline & $\begin{array}{l}\text { Control } \\
\text { Group }\end{array}$ & $n=0$ & $n=0$ & $n=3$ & $\mathrm{n}=17$ & $\mathrm{n}=0$ & $n=1$ & $n=4$ & $n=15$ \\
\hline & $\begin{array}{l}\text { Study } \\
\text { Group I }\end{array}$ & $n=1$ & $n=0$ & $n=7$ & $n=12$ & $\mathrm{n}=6$ & $n=7$ & $n=2$ & $n=5$ \\
\hline & $\begin{array}{c}\text { Study } \\
\text { Group } 2\end{array}$ & $n=2$ & $\mathrm{n}=0$ & $n=7$ & $n=11$ & $n=8$ & $n=2$ & $\mathrm{n}=4$ & $n=6$ \\
\hline & $\begin{array}{l}\text { Control } \\
\text { Group }\end{array}$ & $n=0$ & $n=0$ & $n=3$ & $n=17$ & $\mathrm{n}=0$ & $n=1$ & $n=4$ & $n=15$ \\
\hline 30 & $\begin{array}{c}\text { Study } \\
\text { Group I }\end{array}$ & $n=1$ & $n=0$ & $n=7$ & $n=12$ & $\mathrm{n}=4$ & $n=7$ & $n=3$ & $n=8$ \\
\hline & $\begin{array}{c}\text { Study } \\
\text { Group } 2\end{array}$ & $n=2$ & $n=0$ & $n=7$ & $n=11$ & $\mathrm{n}=6$ & $n=3$ & $n=3$ & $n=8$ \\
\hline & $\begin{array}{l}\text { Control } \\
\text { Group }\end{array}$ & $\mathrm{n}=0$ & $\mathrm{n}=0$ & $\mathrm{n}=0$ & $n=20$ & $\mathrm{n}=0$ & $n=2$ & $n=6$ & $n=12$ \\
\hline $\begin{array}{c}60 \\
\text { Minutes }\end{array}$ & $\begin{array}{l}\text { Study } \\
\text { Group I }\end{array}$ & $n=0$ & $n=0$ & $n=8$ & $n=12$ & $\mathrm{n}=4$ & $n=5$ & $n=3$ & $n=8$ \\
\hline & $\begin{array}{c}\text { Study } \\
\text { Group } 2\end{array}$ & $n=0$ & $\mathrm{n}=0$ & $n=8$ & $n=12$ & $\mathrm{n}=6$ & $n=2$ & $n=4$ & $\mathrm{n}=8$ \\
\hline & $T$ & 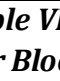 & 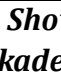 & (5e & npar & $\mathbf{I S O}$ & ups & & \\
\hline
\end{tabular}

Motor blockade in the 3 groups showed that in Study Group I and Study Group II there is lesser degree of motor blockade when compared to the Control group. This difference was found to be statistically significant.

Sensory Blockade

\begin{tabular}{|c|c|c|c|}
\hline & $\begin{array}{c}\text { Control } \\
\text { group }\end{array}$ & $\begin{array}{c}\text { Study } \\
\text { Group I }\end{array}$ & $\begin{array}{c}\text { Study } \\
\text { Group II }\end{array}$ \\
\hline Upper Level & $\mathrm{T}_{6}-\mathrm{L}_{1}$ & $\mathrm{~T}_{9}-\mathrm{T}_{12}$ & $\mathrm{~T}_{8}-\mathrm{T}_{12}$ \\
\hline \multicolumn{3}{|c|}{ Table VII: Shows Comparison of Sensory } \\
Blockade in all Three Groups \\
\hline
\end{tabular}

There was no statistical difference in the upper level of sensory blockade.

The onset time for loss of pinprick sensation at $\mathrm{T}_{10}$ in both the limbs in all the three study groups was similar between 5 to 7 minutes. We are not able to demonstrate any obvious difference in onset times.

\section{DISCUSSION}

This prospective randomised study was done in 60 high-risk patients of ASA II and III category with comorbid factors and potential for haemodynamic instability were drafted into the study. The practicality of producing a unilateral spinal block and ability to reduce haemodynamic instability was studied. The ability of a low-dose bupivacaine subarachnoid block in combination with fentanyl in maintaining a unilateral spinal block and its ability to decrease haemodynamic alteration was also studied.

\section{Unilateral Spinal Anaesthesia}

After performance of Subarachnoid block in the lateral position (Operated limb kept dependent), patients were maintained in the lateral position for 10 minutes before turning them supine.

In this study, the onset time for loss of pinprick sensation at $\mathrm{T}_{10}$ in both the limbs in all the three study groups was similar between 5 to 7 minutes. In this study, we were not able to demonstrate any obvious difference in onset times.

In this study, the sensory block had a wide variation in the upper level of block between the dependent and nondependent limb at 15 minutes. But with the passage of time this difference was narrowed or obliterated.

The median level of block was between $\mathrm{T}_{9}-\mathrm{T}_{10}$ in all 3 groups. The level of block in control group extended between $\mathrm{T}_{6}$ to L1. In the Study Group I, the block extended between T9$\mathrm{T}_{12}$. In the Study Group II, the block extended between $\mathrm{T}_{8}$ and $\mathrm{T}_{12}$.

In our study, there was no statistical difference in level of sensory blockade between the dependent and non-dependent leg. The initial difference observed between the 2 limbs due to maintenance of lateral position is lost to a great extent on assumption of the supine position.

\section{Motor Block}

An analysis of motor blockade in the 3 groups showed that unilateral spinal block and low-dose spinal block introduced lesser degree of motor blockade when compared to the classical subarachnoid block group. This difference was found to be statistically significant.

\section{Two Space Regression}

In our study, we were unable to demonstrate any statistically significant difference in the two space regression of sensory block on the dependent limb when compared to the nondependent limb in the three groups studied.

\section{Haemodynamic Stability and Complications}

In our study, haemodynamic stability as evidenced by systolic blood pressure, diastolic blood pressure and mean arterial blood pressure was comparable between Study Group I and II. Three patients had hypotension of more than $30 \%$ from baseline values that required treatment. Control group had higher incidence of both hypotension and bradycardia with 6 patients requiring treatment with vasopressors, and fluids (Crystalloid) for both these complications. 
Study Group I and II had lesser incidence of haemodynamic problems. These difference was also found to be statistically significant.

\section{Motor Blockade}

Analysis of motor block was done using Modified Bromage Scale both in the dependent and non-dependent limb exclusively.

The control group had maximum degree of motor blockade with $17 / 20$ patients having grade 3 motor blockade in both limbs. Study Group I had grade 3 motor blockade in $11 / 20$ patients and the Study Group II had motor blockade of grade 3 in 12/20 patients. From this study, it was found that the unilateral spinal and low-dose subarachnoid block decreases the degree of motor blockade which was statistically significant. Analysis was done to see if there is any difference in the degree of motor blockade between the two limbs (Dependent vs. non-dependent, where applicable). Comparisons were made at 15, 30 and 60 minutes interval. Grade II and III of modified Bromage scale were considered as significant motor blockade of limb. Based on these parameters the following observations were made.

\section{Control Group}

This group showed no statistically significant difference in motor blockade between the limbs. Degree of motor blockade was recorded at 15 mins. and 60 mins. and also were compared between the two limbs.

\section{Study Group I}

This group showed a statistically significant difference in motor blockade between the two limbs at 15 mins. Significant motor blockade in dependent limb was $17 / 20$ and in nondependent limb was 10/20. At 60 mins., significant motor blockade in the dependent limb was $20 / 20$ and in the nondependent limb was 12/20.

\section{Study Group II}

This group showed statistically significant motor block on dependent limb 19/20 versus the non-dependent limb 7/20 at 15 minutes. This reflects that onset time is faster and denser in the dependent limbs. At 60 mins., the dependent limb had significant motor blockade of $20 / 20$ while in the non-dependent limb motor blockade was $11 / 20$. So as the time elapsed the differential blockade obtained between the two limbs seems to have reduced probably reflecting slow spread of local anaesthetics to the non-dependent limb also on assumption of supine position.

\section{CONCLUSION}

From this study, we conclude that in high-risk patients undergoing unilateral lower limb surgeries, unilateral lowdose subarachnoid block offers better haemodynamic stability during the intraoperative period.

The onset and quality of level of sensory block in unilateral subarachnoid and low-dose unilateral subarachnoid block is same as those produced by classical subarachnoid block.

There is sparing of motor block in the non-dependent limb in unilateral subarachnoid block and unilateral low-dose subarachnoid block.

\section{REFERENCES}

1. Brooker RF, Butterworth JF, Kitzman DW, et al. Treatment of hypotension after hyperbaric tetracaine spinal anaesthesia. A randomized, double-blind, crossover comparison of phenylephrine and epinephrine. Anaesthesiology 1997;86(4):797-805.

2. Carr DB, Cousins MJ. Spinal route of analgesia, opioids and future options. $3^{\text {rd }}$ edn. In: Cousins MJ, Bridenbaugh PO, eds. Neural blockade in clinical anaesthesia and management of pain. Philadelphia: Lippincott-Raven 1998:915-75.

3. Carpenter RL, Liu SS, Hogan QH, et al. Lumbosacral CSF volume is the primary determinant of sensory block extent and duration during spinal anaesthesia. Anaesthesiology 1998;89(1):24-9.

4. Casati A, Fanelli G, Cappalleri G, et al. Effects of speed of intrathecal injection on unilateral spinal by $1 \%$ hyperbaric bupivacaine. A randomized, double-blind study. Minerva Anestesiol 1999;65(1-2):5-10.

5. Frank A, Schuster M, Biscoping J. Influence of positioning on the quality of unilateral spinal anesthesia. Anasthesiol Intensivmed Notfallmed Schmerzther 2002;37(11): 659-64.

6. Gentili ME, Mamalle JC, Folle LG. Combination of low dose bupivacaine and clonidine for unilateral subarachnoid block in arthroscopy knee surgery. Reg Anesth 1995;20(2):169-70.

7. Neigh JL, Kane PB, Smith TC. Effects of speed and direction of injection on the level and duration of spinal anaesthesia. Anesth Analg 1970;49(6):912-8.

8. Pitkanen M. Slow injection of $0.5 \%$ plain bupivacaine increases level. Reg Anesth 1992;17(Suppl 26):35-8.

9. Povey HM, Jacobsen J, Westergaard-Nielson J, et al. Subarachnoid analgesia with hyperbaric $0.5 \%$ bupivacaine: effect of a 60 -min period of sitting. Acta Anaesthesiol Scand 1989;33(4):295-7.

10. Stienstra R, Gielen M, Kroon JW, et al. The influence of temperature and speed of injection on the distribution of a solution containing bupivacaine and methylene blue in a spinal canal model. Reg Anesth 1990;15(1):6-11.

11. Liu SS, McDonald SB. Current issue in spinal anaesthesia. Anaesthesiology 2001;94(5):888-906.

12. Tanasichuk MA, Shultz EA, Matthews JH, et al. Spinal hemianalgesia, an evaluation of a method and its applicability and influence on the incidence of hypotension. Anaesthesiology 1961;22:74-85. 